\title{
The Scientific and Religious Exploration of the World in the Name of God. \\ Jesuit Missionaries as Anthropologists and Natural Scientists in the New World. \\ With a Focus on the Swiss Jesuit Philipp Segesser
}

\author{
Albrecht Classen \\ University of Arizona \\ aclassen@email.arizona.edu \\ https://dx.doi.org/10.12795/futhark.2011.i06.03
}

\begin{abstract}
In jüngster Zeit hat sich viel Interesse an der Arbeit jesuitischer Missionare in der Neuen Welt des 17. und 18. Jahrhunderts geregt, weil deren Leistungen in praktischer und theoretischer Hinsicht unübersehbar gewesen sind, ganz gleich was die sogenannte 'Schwarze Legende' über sie zu verbreiten versuchte. Viele dieser Missionare, von denen erstaunlich viele aus der deutschen Provinz kamen, hinterließen z.T. sehr umfangreiche wissenschaftliche Werke, manche sogar enzyklopädischer Natur. Dazu besitzen wir viele Korrespondenzen. Aus kulturhistorischer Sicht können wir darin einen recht beachtlichen Beitrag zur wissenschaftlichen Erforschung der jeweiligen Missionsgebiete erkennen, auch wenn die Missionare stark durch ihre westliche und vor allem christliche Sicht geprägt waren. Neuere transkulturelle Perspektiven in der Germanistik haben dazu geführt, in diesen Schriften der Jesuiten wichtige schriftliche Zeugenaussagen und Selbstreflexionen zu erkennen. Hier aber geht es darum, das wissenschaftliche Interesse der Missionare in den Blick zu nehmen, wozu besonders die Briefe und ein größerer Bericht des Schweizer Jesuiten Philipp Segesser (1689-1762) dienlich sind. Die ersteren werden demnächst in englischer Übersetzung erscheinen, und der gegenwärtige Aufsatz vermittelt wichtige Erkenntnisse darüber, welche wissenschaftlichen Studien dieser Missionar durchführte.
\end{abstract}

Abstract: Recently the interest in the work of the Jesuit missionaries in the New World during the seventeenth and eighteenth centuries has grown considerably because their accomplishments in practical and theoretical terms have been undeniable, irrespective of what the so-called 'Black-Legend' tried to convey about them. Many of these missionaries, a large percentage of whom had 
originated from the German province, left behind in part very voluminous scientific works, some of which were even of encyclopedic nature. In addition there are numerous correspondences. From a cultural-historical perspective we can recognize in these documents important contributions to the scientific exploration of the respective missionary areas, even though the Jesuits were certainly determined by their Western and especially Christian perspective. New transcultural approaches in German Studies have allowed us to recognize in these texts by the Jesuits important written witness accounts and self-reflections. But the topic of the present study focuses on the missionaries' scientific interests, as we can recognize it especially in the letters and one larger report by the Swiss Jesuit Philipp Segesser (1689-1762). The former will soon appear in print in English translation. The present article relays important insight into what kind of scientific research this missionary carried out.

Keywords: Eighteenth century - Jesuits - New World - modern sciences - Philipp Segesser - letters

We are wont to imagine scientists normally working in university settings, in libraries, in observatories, or in laboratories, here disregarding those who are involved with practical field work. It might come as a surprise to discover early modern scientists far afield, roaming distant lands, and dedicating their lives to the challenging task of missionizing non-Christian people, while doing serious, ground-breaking research at the same time, as far as that was possible under those circumstances. But this was often the case with European Jesuits who went out into the entire world as teachers, preachers, and fighters for the Christian faith to fulfill their pledge to educate, to missionize, and to convert those who had been lost to the Catholic Church or had never heard a word about the Christian faith. ${ }^{1}$ Founded in 1540 by the Basque Ignatius Loyola , the Jesuit Order quickly developed into a global organization and gained enormously in respect for many different purposes, such as their religious fervor, their

1. For a wealth of perspectives in this regard, see the contributions to The Jesuit Tradition in Education and Missions: A 450-Year Perspective, ed. Christopher Chapple (Scranton: University of Scranton Press, and London and Toronto: Associated University Presses, 1993), especially the studies by Francesco C. Cesareo and Joseph A. O'Hare, S.J.

Futhark 6 (2011) Classen, The Scientific and Religious Exploration, 49-

67

ISSN 1886-9300 
military structure and discipline, and their absolute dedication to the ideal of spreading Christianity through missionizing activities. ${ }^{2}$

Their school system, which was an integral element of the Jesuit concept, appealed to people far and wide, which became one major catalyst for Catholicism to regain considerably new and old ground in Europe throughout the sixteenth through eighteenth centuries. ${ }^{3}$ Wherever Jesuits established a new educational institute (school, collegium, university, etc.), they soon attracted pupils and students from the upper classes and wealthy burghers who realized that their children could gain a most valuable enhancement both in intellectual and social terms at those institutions. ${ }^{4}$ At the same time the Jesuits made great efforts to participate in the most far-reaching and innovate research, both for pragmatic and religious reasons. Most impressively, they had established more than 650 educational institutions already by the eighteenth century. ${ }^{5}$ They were well aware, for instance, that they would only have a chance to combat with success the deep impact of the Protestant Reformation throughout Europe and to realize the Catholic Counter-Reformation if they could offer people new perspectives, ideals, and a value system that the old Catholic Church had mostly lost during the late Middle Ages. ${ }^{6}$ The great successes of the Catholic Church in Italy, France, Austria, and southern Germany during the sixteenth and

2. See, most recently, Rita Haub, Die Geschichte der Jesuiten (Darmstadt: Wissenschaftliche Buchgesellschaft, 2007), 36-70.

3. Ugo Baldini, Saggi sulla cultura della Compagnia di Gesù (secoli XVI-XVIII) (Padua: CLEUP, 2000); M. T. Borgato, Giambattista Riccioli e il merito scientifico dei gesuiti nell'età barocca. Biblioteca di Nuncius. Studi e testi, 44 (Florence: L. S. Olschki, 2002); Marcus Hellyer, Catholic Physics: Jesuit Natural Philosophy in Early Modern Germany (Notre Dame, IN: University of Notre Dame Press, 2005).

4. Judi Loach, "Revolutionary Pedagogues? How Jesuits Used Education to Change Society," The Jesuits II: Cultures, Sciences, and the Arts 1540-1773, ed. John W. O'Malley, S.J., Gauvin Alexander Bailey, et al. (Toronto, Buffalo, and London: University of Toronto Press, 2006), 66-85.

5. Ignatius von Loyola und die Pädagogik der Jesuiten: Ein Modell für Schule und Persönlichkeitsbildung, ed. Rüdiger Funiok and Harald Schöndorf. Geschichte und Reflexion (Donauwörth: Auer, 2000); Jonathan Wright, God's Soldiers: Adventure, Politics, Intrigue, and Power: a History of the Jesuits (New York: Doubleday, 2004).

6. John O'Malley, "The Society of Jesus," A Companion to the Reformation World, ed. R. Po-chia Hsia. Blackwell Companions to European History (Malden, MA, Oxford, and Victoria, Australia: Blackwell, 2004), 223-36. See also the chapters in the same volume by Ines G. Županov (ch. 21), R. Po-chia Hsia (ch. 22), and Michael Cooper (ch. 23).

Futhark 6 (2011) Classen, The Scientific and Religious Exploration, 4967

ISSN $1886-9300$ 
seventeenth centuries speak volumes. Moreover, until today, Jesuit schools and universities dot the landscape all over the world, all of them heirs of a brilliant intellectual and religious movement initiated by Loyola. ${ }^{7}$

Of course, their successes also evoked a lot of fear, jealousy, and envy all over the world wherever they appeared and set up 'shop,' so to speak; hence the emergence of the so-called 'Black Legend' targeting the Jesuits at large had a tremendous impact on popular opinion from early on. There were many reasons for the banning of the Jesuit Order on a global level in 1767, some political, others religious, not to forget extensive economic ones. ${ }^{8}$ But we can also point to the enormous educational achievements by the Jesuits, which made them, ironically, to a fairly easy target of opposition and enmity from many different sides, particularly among the aristocracy and the traditional clergy, not to speak of the secular educational institutions. Not surprisingly, the other traditional monastic orders were at the forefront of this negative campaign and happily took over much of the structures which the Jesuits had to leave behind after their ban.

The Jesuits were not only concerned with rejuvenating the educational system back home in early modern Europe to roll back the consequences of Luther's enormous 'revolutionary' activities. They had actually much larger goals in mind, reaching out to peoples all over the globe, even in those continents where high levels of civilization were the

7. Michael J. Buckley, The Catholic University as Promise and Project: Reflections in a Jesuit Idiom (Washington, DC: Georgetown University Press, 1998).

8. Eva Mariá St. Clair Segurado, Expulsión y exilio de la provincia jesuita mexicana 17671820 (San Vicente del Rasperig: Publicaciones de la Universidad de Alicante, 2005); El saber de los jesuitas, historias naturales y el Nuevo Mundo, ed. Luis Millones Figueroa and Domingo Ledeyma. Textos y estudios coloniales y de la Independencia, 12 (Frankfurt: Vervuert; Madrid: Iberoamericana, 2005); Enrique Villalba Peárez, Consecuencias educativas de la expulsión de los Jesuitas de América (Madrid: Biblioteca del Instituto Antonio de Nebrija de Estudios sobre la Universidad, 2003); Los jesuitas espanoles expulsos: Su imagen y su contribucion al saber sobre el mundo hispanico en la Europa del siglo XVIII: Actas del coloquio internacional de Berlín (7-10 de abril de 1999) publicadas por Manfred Tietz en colaboración con Dietrich Briesemeister. Biblioteca Ibero-Americana, 76 (Madrid: Iberoamericana: Frankfurt a. M.: Vervuert, 2001).

67

ISSN 1886-9300 
norm harking back to ancient times, such as China, Japan, and India. ${ }^{9}$ The Jesuits were entirely clear about the absolute need to send no one else but their very best schooled and trained representatives to the Far East because only if these could impress the Chinese emperor and his court astronomers, for instance, would they have a chance to reach out to them and interest them in the Christian teachings. Some of their missionaries were almost too successful for the taste of those back home because some of them adapted almost too well to the Chinese culture, acquiring the linguistic skills necessary for their tasks, adopting the local costumes and clothing, and thus were almost in the danger, as some critics voiced, to lose themselves to the Asian world altogether (see, for instance, Matteo Ricci [1552-1610]). ${ }^{10}$

The purpose of this paper cannot be to retrace the entire history of the Jesuit Order, which has attracted many historians and theologians for a long time, who have also noted the astounding contributions by German-speaking Jesuits since the eighteenth century. ${ }^{11}$ Similarly, the contributions by Jesuits to early modern science has also been the object of intensive discussions, which I can only touch upon here. ${ }^{12}$

9. J. S. Cummins, A Question of Rites: Friar Domingo Navarrete and the Jesuits in China (Hants: Scolar Press, 1993); Luke Clossey, Salvation and Globalization in the Early Jesuit Missions (Cambridge: Cambridge University Press, 2008).

10. J. H. Dunn, Generation of Giants: the Story of the Jesuits in China in the Last Decades of the Ming Dynasty (Notre Dame, IN: University of Notre Dame Press, 1962). See also the contributions to Mission und Theater: Japan und China auf den Bühnen der Gesellschaft Jesu, ed. Adrian Hsia and Ruprecht Wimmer. Jesuitica, 7 (Regensburg: Schnell \& Steiner, 2005). Most recently, this history has also been studied by Liam Matthew Brocke, Journey to the East: the Jesuit mission to China, 1579 - 1724 (Cambridge, MA, and London: The Belknap Press of Harvard University Press, 2007).

11. For an early, but highly informative, study, see Bernhard Duhr S.J., Deutsche Auslandssehnsucht im achtzehnten Jahrhundert: Aus der überseeischen Missionsarbeit deutscher Jesuiten. Schriften des Deutschen Ausland-Instituts Stuttgart. A. Kulturhistorische Reihe, 20 (Stuttgart: Ausland und Heimat, 1928).

12. Johannes Meier, "Totus mundus nostra fit habitatio": Jesuiten aus dem deutschen Sprachraum in Portugiesisch- und Spanisch-Amerika. Akademie der Wissenschaften und der Literatur. Abhandlungen der Geistes- und sozialwissenschaftlichen Klasse, 2000, Nr. 2 (Mainz: Akademie der Wissenschaften und der Literatur; Stuttgart: Franz Steiner Verlag, 2007), offers numerous references to highly learned treatises by German-speaking Jesuit scholars working on the South-American languages, cultures, and histories. See now his Jesuiten aus Zentraleuropa in Portugiesisch- und Spanisch-Amerika: Ein biobibliographisches Handbuch mit einem Überblick über das aussereuropäische Wirken Futhark 6 (2011) Classen, The Scientific and Religious Exploration, 4967 
Instead, the focus will rest on those Jesuit missionaries who took it upon themselves since the late eighteenth century to venture into the area of northern Mexico, at that time called Pimería Alta, whereas today Sonora and Arizona. More specifically, my goal is to investigate some of the scientific contributions by those Jesuits who had left the German speaking lands - the Upper German Province of the Jesuit Order which also included Bohemia, Croatia, Tyrol, and other outlying areas-and had spent many years in Sonora about which they later composed lengthy treatises, reports, and even encyclopedias. Of course, until 1767 virtually all Jesuit missionaries never left the New World again and spent the rest of their lives there.

Padre Eusebio Kino (1645-1711) was the first to enter those arid lands and to quickly set up a whole chain of missions which soon turned into a whole network where other missionaries served on his behalf. The Jesuits altogether proved to be highly successful in that region, among many others all over the world, considering the constant flow of new missionaries who followed Kino's model, many of whom actually arrived from the German province. ${ }^{13}$ Here I will concentrate on the Swiss Jesuit Philipp Segesser, who played a significant role in the administration of the Sonora province, and his personal correspondence which will allow us to get an excellent insight into the daily work of such missionaries and to learn what scientific and other interests they also pursued along their religious duties.

Anthropologists, ethnologists, and historians of religion have examined this extraordinary phenomenon from many different perspectives. Some of these interests have centered on what we can learn about the agricultural activities at those missions-creating food for

der Gesellschaft Jesu in der frühen Neuzeit, ed Johannes Meier. Vol. 1: Brasilien (16181760), by Fernando Amado Aymoré (Münster: Aschendorff Verlag, 2005).

13. The exploration of the work and contributions by German-language Jesuit missions in the Southwest has begun already several decades ago, see Bernd Hausberger, Jesuiten aus Mitteleuropa im kolonialen Mexiko: Eine Bio-Bibliographie. Studien zur Geschichte und Kultur der iberischen und iberoamerikanischen Länder, 2 (Vienna and Munich: Verlag für Geschichte und Politik, 1995); Albrecht Classen, "Padre Eusebio Kino - ein österreichischitalienischer Missionar aus Tirol in Sonora/Mexiko und Arizona," Mitteilungen des Instituts für Österreichische Geschichtsforschung 105 (1997): 441-66.

67 
those willing to join the missionaries and providing protection from other hostile Indians regularly proved to be the most essential and most effective means to attract members of various tribes who were then willing to listen to the missionaries' teachings and sermons-the architecture, the political structure, the missionaries' connections with the local population, their efforts to learn the native languages-a crucial stepping stone for all missionary activities until today-and on how they observed the world around them in pragmatic and scientific terms. ${ }^{14}$

In 1767 the history of the Jesuits suddenly came to an abrupt end because the entire order was banned, all missions were dissolved, and every Jesuit was forcefully removed from the New World and elsewhere, thrown into prisons or kept in monastic cells as a form of punishment for a crime that was never spelled out, meaning that there was never any trial or official statement as to their alleged guilt. Many died already on their way home to Europe, others lingered in various prisons for years, and some ultimately made it back to their native countries. As a side note, the Jesuits were readmitted in 1814 , but that will not concern us here.

In particular, the Swiss Jesuit Philipp Segesser (1689-1762) from Lucerne deserves our interest here because we have a singularly large number of letters from him which he sent to his family back home over several decades until his death in 1762, documenting in a remarkable fashion how he adjusted to the New World and how he learned to cope there in a completely strange environment. ${ }^{15}$ In 1737 he also composed a lengthy report in which he provided a very thorough survey of the geography, the climate, the fauna and flora of Sonora. ${ }^{16}$ Combined with

14. Ursula Ewald, Studien zur Entstehung, Wirtschafts- und Sozialstruktur der kolonialen Hacienda in Mexiko. Das Mexiko-Projekt der Deutschen Forschungsgemeinschaft, 9 (Wiesbaden: Steiner, 1976) (also in Spanish); Esclavitud, economía y evangelización: las haciendas jesuitas en la América virreinal, ed. Sandra Negro Tua andManuel M. Marzal (Lima, Perú: Pontificia Universidad Católica del Perú, 2005).

15. Heiko Schmuck, Philipp Segesser SJ (1689-1762): Exemplarische Biographie eines mitteleuropäischen Missionars in Nueva España. Mainzer Studien zur Neueren Geschichte, 11 (Frankfurt a. M., Berlin, et al.: Peter Lang, 2004).

16. Philipp A. von Segesser, "Die Berichte des P. Philipp Segesser aus der Gesellschaft Jesu über seine Mission in Sonora, 1731-1761," Katholische Schweizer-Blätter für Wissenschaft, Kunst und Leben N.F. 2 (1886): 356-75, 401-34, 465-99; this also appeared as a separate book publication the same year. I had available a copy bound together with Futhark 6 (2011) Classen, The Scientific and Religious Exploration, 4967 
the information that we can glean from those texts in which his predecessors and successors recorded their observations, we can gain a solid understanding of what kind of scientific perceptions and other interests these Jesuit missionaries pursued and how they approached their tasks as scientists, administrators, teachers, and priests. Of course, they stood in the tradition of late-medieval and early-modern sciences, but they also turned their attention very much to empirical studies and can thus be viewed as important forerunners, if not leaders, in the fields of botany, geography, climatology, biology, linguistics, and anthropology, as these slowly emerged in the eighteenth century. ${ }^{17}$

Eusebio Kino was truly famous, above all, for his cartographic skills; his maps of the Pimería Alta gained great respect in Europe and were incorporated into most of the relevant atlases and related geographical handbooks far into the nineteenth century. Ignaz Pfefferkorn (1725-after 1795) and Joseph Och (1725-1773) collected, independently from each other, vast amounts of data pertaining to the Sonoran province and recorded those in rather massive scientific works, examining the entire spectrum of the features relevant for the nature and culture of that world, discussing also the languages, religions, customs, and mentality of the native population. ${ }^{18}$ Significantly, this was not unusual for Jesuits, considering their centralized organization, hence their need to maintain good control and discipline throughout their worldwide network, and the constant central emphasis on their educational mission. Letters from the entire world arrived at their centers,

other smaller booklets in the Staatsarchiv Luzern (no cover). For the English translation, see Theodore E. Treutlein, "The Relation of Philipp Segesser," Mid-America: An Historical Review NS. 16 [27), 3 (1945): 139-260. The text was also translated into Spanish, which confirms its enormous significance for anthropologists and historians alike: La relación de Philipp Segesser: Correspondencia familiar de un misionero en Sonora en el año de 1737, trans. Armando Hopkins Durazo (Hermosillo: n.p., 1991)

17. Los jesuitas y la ciencia: los límites de la razon, ed. José Luis Bermeo (Mexico: Artes de México, 2007).

18. Johannes Meier, "Ein Leben zwischer Alter und Neuer Welt: P. Joseph Och (17251773), Jesuit aus Würzburg und Missionar in Mexiko," Würzburger Diözesangeschichtsblätter 69 (2007): 377-86.

67 
many of which were then translated and/or collected and published, such as in the famous Welt-Bott, edited by Joseph Stöcklein. ${ }^{19}$

Whereas the detailed descriptions of the natural phenomena might not come as a surprise to us, considering the Jesuits' solid education, we would have to judge the sensitivity and insightfulness of their anthropological studies as rather amazing. Although the Jesuits worked as missionaries and thus were driven by very explicit Eurocentric and Christian concepts and values, regularly leading to rather contemptuous and arrogant perspectives toward the native population, they were open and tolerant enough to present their personal observations of cultural practices, linguistic features, and religious rituals in a remarkably detailed and insightful manner. Of course, typical of their time and cultural background, the Jesuit missionaries deeply lamented the presumed lack of rationality and stubbornness among the natives who were rather disinclined to abandon their old faiths; but they also portrayed them with great admiration and praise regarding their physical skills and their abilities as craftsmen, artists, and musicians.

All these issues have already been discussed in one way or the other, and in a variety of contexts, depending on the availability of sources. Both Pfefferkorn and Och were particularly successful in this regard because they set down to write their extensive accounts only well after their forceful return to Europe. Many other missionaries reached out to a diverse group of listeners (officials, superiors, family members), but then usually only in the form of personal letters, most of which have never been made available in modern editions or translations. This was the case with the Lucerne Jesuit Philipp Segesser as well, but his

19. Joseph Stöcklein, Allerhand So Lehr=als Geist=reiche Brief / Schrifften und Reis=Beschreibungen Welche von denen Missionariis der Gesellschafft Jesu aus Beyden Indien / und andern über Meer gelegenen Laendern / Seit Anno 1642. bis 1726. in Europa angelangt seynd. Jetzt zum erstenmal Theils aus Handschrifftlichen Urkunden / theils aus denen Franzoesischen Lettres Edifiantes verteutscht und zusammen getragen von Josepho Stöcklein. Part 8: Von Anno 1720. Biß 1725. (Augsburg and Graz: Philipp / Martin / und Johann Veit seel. Erben, 1726); Albrecht Classen, "Missionarische Bemühungen als Welterforschung. Jesuitische Sichtweisen auf die Neue Welt: nördliches Mexico heutiges Arizona," Scientiae et artes: Die Vermittlung alten und neuen Wissens in Literatur, Kunst und Musik. Vol. II. Ed. Barbara Mahlmann-Bauer. Wolfenbütteler Arbeiten zur Barockforschung, 38 (Wiesbaden: Harrassowitz, 2004), 1029-51.

67 
complete correspondence will soon appear in English translation. ${ }^{20}$ Insofar as he composed his letters commonly in an ad-hoc fashion, normally under enormous time pressure in order to utilize the opportunity of a messenger who was about to depart, we cannot expect a fully systematic presentation and analysis, like in the treatises by Pfefferkorn and Och, in the extensive reports by Johann Jakob Baegert (1717-1772) and Johann Nentvig (1713-1768), or in the diary by Bernhard Middendorf $(1723-1782) .{ }^{21}$ Nevertheless, particularly because of their personal, private, character, Segesser's letters allow us to gain solid insight into how one of these many Jesuit missionaries approached his task not only to set up a mission itself or to work toward the goal of preaching to the native population, hoping to convert them to Christianity, but also how this European traveler and researcher observed his natural and social environment in northern Mexico at the frontier of the Spanish empire. Of course, he was not a forerunner of Alexander von Humboldt (1769-1859) and his generation of nineteenth-century scientists and naturalists, ${ }^{22}$ yet Segesser, very much like his fellow Jesuit missionaries, demonstrated a keen eye, a sharp sense of his new environment, and a considerable interest in investigating every aspect of it for his own profit and that of his readers back home.

As to be expected, virtually all of his letters which he addressed to his parents or his siblings are usually limited mostly to personal aspects and do not tell us much at all about his studies or his professional activities, apart from those that pertain to the Jesuit Order, his growing into the novitiate, taking his vows, etc. Then, those letters that pertain to the period in Sevilla and Cadiz where he waited for a transport to the New World, and those that reflect on his arrival in Mexico and on his journey north to Sonora where he set up his mission and

20. Philipp Segesser SJ, Letters to his Family in Switzerland, trans. Albrecht Classen (forthcoming).

21. Hausberger, Jesuiten aus Mitteleuropa, provides detailed bibliographies and biographies for all of them.

22. Aaron Sachs, The Humboldt Current: A European Explorer and his American Disciples (Oxford and New York: Oxford University Press, 2007); see also the contributions to Viajes y viajeros entre ficción y realidad. Alemania-España, ed. Berta Raposo Fernández and Ingrid García Wistädt (Valencia: Universitat de València, 2009).

67

ISSN 1886-9300 
began with his life-long work preaching to the native population, are also too specific and often very personal to include references revealing his scientific interests and studies. For a long time, as to be expected, the mundane needs to set up a mission, to get the garden, farm, and husbandry working, dominate his interests. Nevertheless, insofar as these letters served as a kind of running diaries and reflect many different aspects in the missionary's daily life, we can investigate them as important mirrors of his mind-set and personal experiences, representative of a whole generation of eighteenth-century Jesuit missionaries.

Segesser repeatedly wrote extensive letters to his brother Franz Ulrich requesting very specific items needed in the kitchen and on a farm, such as on January 15, 1731, briefly after his arrival in San Xavier del Bac, today just south of Tucson: "However, I do not ask for money, but items tantamount to money. I would not request those if all that were available in America that will be useful and very necessary for my household. These are things that seem to be contemptible and hardly worth to be shipped over such a distance. Nevertheless, I do not request them not without good reason.

Although one might think that a missionarius should forget about such things, you must not forget that the Indians, when the Pater missionarius does not help them with food and clothing, all escape back into the mountains and the caves, where they have been called and lured forth with great trouble. But how will that what I have requested help the Indians? Answer: One follows from the other. For instance: I request a scythe. With this I can make hay because grass is growing in great quantities here. The cows eat hay, so they can be raised in the shed (otherwise, if kept on the field, they stay wild). These provide me with milk, the milk in turn makes cheese and butter (truly, a very appropriate discourse for me!), for the cheese and the butter I can barter other land, clothing, salt, spices, etc., as here in this land items are bartered, good for good. So, when I urgently plead with you, then for objects that I can barter here best with."

As to be expected, apart from the natural world Segesser was fascinated by the people in and around his mission, although he mostly felt contempt for them, regarding them at times as little more advanced, or cultivated, than animals. Nevertheless, he took great care to listen to

67 
their reports about the devil and whatever they might have believed: "It appears that this part of the earth has until now been the residence of the living Satan, although I do not find any particular superstition here. However, here are many who have their dialogue with the devil who appears to them in different shape, once in that of a wolf, then in that of an ape, often as a black moor, etc. He instruct them how they can harm people and kill them. One of these devils has killed more than 40 people in the winter in my mission. The devil puts a horrible material into their mouths or stomach, which the devil's servants [these are now the Indians] copy by blowing it through a certain feather-pipe into the bodies of those whom they want to harm, without being noticed. Those then die after few days with great pain, because there are no remedies to be found here. I have seen it all with my own eyes and stood next to the death beds of many, as I will later describe it in greater detail" (June 8, 1732).

Segesser clearly took note of their religious practices, described them fleetingly, but also admitted that there was nothing he could do to change anything in their beliefs and spirituality or convince them of abstaining from their traditional rituals: "Every night my Indians tend to repeat their immense screams, dances, and singing until the early morning so that I cannot find any restful sleep, or find a means to stop such things. After all, it is necessary to win over these minds with love step by step so that they, tired of the Pater, do not attack and kill him, although such a death would be more desirable since I think that I will not receive any more good in my present life. After all, where does one find another life in these countries? By and by one makes progress" (ibid.).

Certainly rather unsystematically, yet observant to the many details, Segesser happily outlined what animals, reptiles, flies and mosquitoes he had witnessed: "Moreover, at this time of the year there are many dangerous and poisonous vermin, mosquitoes and flies without end. Here are toads as big as a fully grown royal hare, or küngelein, as it is called at home, although one of them frightened me not little recently which hopped around the altar during my Mass. Then there are more snakes, vipers, alagran [scorpions], poisonous and spiders than you can fend off, so I can never sleep safely. Everything comes to life around the bed at night. There are countless rats and mice. Two dangerous wounds

67 
from a poisonous scorpion bite in two of the feet [of some of the people there] I immediately healed these within days with the gracia Sancti Pauli although they were already greatly swollen up and filled with puss" (Sept. 10, 1732).

Many times Segesser provided detailed accounts of the customs and rituals practiced by the Indians. He knew only too well that he could not do much at all to intervene and stop them, but he clearly displayed considerable interest and allowed his reader to understand some of the religious culture in the New World: "They dance the whole night, thus organize big celebrations and sponsalia [wedding festivities]. In this way they marry that young girl and that boy with each who last the longest in the dance. Instead of the music instruments they perform entertainment with horrible screams that have neither sound nor melody. This is a very annoying matter for the Pater Missionary because all this prevents him from finding sleep. I have often told them to go further away, but this was all in vein, and you cannot employ a harsh tone if the missionary does not want to live alone in the mission [the Indians would simply leave him]. In these very dances they exact punishment for those who had an affair with a woman other than their own in the following way" (May 7, 1734).

Although Segesser revealed his great irritation and helplessness, the letter also indicates how much an ethnographer is at work here and tries to grasp as much as possible of this foreign culture and the strange rituals. Both as a missionary and as a scientist he was fully aware that he did not fully comprehend what was going on, what the music, the screaming, or the dances might have meant. Nevertheless, he realized that the entire practice represented something important, yet impervious to his critical eye and mind. Not surprisingly, Segesser also commented at great length on the workings of a sorcerer, particularly because he suffered badly, so he believed, from the effects of his witchcraft (ibid.). Once he was healed again, he reflected upon the perhaps telepathic powers exerted by the sorcerer: "until today I cannot understand how it was possible that the sorcerer could have spat that out of his mouth that he had magically put into my body, that is, he in the prison, I in the bed, in the house of the Pater Rectoris."

None of the other missionary ever made mention of similar occurrences, but they composed 'official' documents for the broader reader audience, whereas here we deal with a private letter in which the

67 
author felt much more freedom to relate such matter. Segesser demonstrated a considerable degree of perplexity about the whole affair because he really got sick, so it seemed, as a result of the sorcerer's efforts, and then regained his health again because the latter had spat out some bitter object out of his mouth, though he was then far away from the missionary. As the author frankly admits: "I do not know what I should believe" (ibid.). We would not necessarily call this a scientific approach, but certainly a rational one based on keeping an open mind and staying away from making absolutist statement from a religious perspective.

Segesser also reported, whenever an opportunity arose, extensively about events that concerned the Indians or were initiated by them, such as revolts, the role of alleged sorcerers, legal and political conflicts, attacks specifically by the Apaches, and then all kinds of murders (August 13, 1741 and June 27, 1742). Then we hear reports about the sighting of a comet: "In the month of March we saw a huge comet on the side of the sunrise early in the morning, which by and by approached the north star and there then disappeared. Last year we saw another one at sunset, but it was not at all as big as the last one" (ibid.). ${ }^{23}$ But these are all only snippets and do not indicate how much Segesser really observed his environment in a scientific and systematic fashion. Segesser also mentions unusual weather conditions: "A few days later another lightning circled around my whole house and the church, but did not cause any harm. It did not dare to overturn the blessing" (Sept. 18, 1750), though he does not probe them further and instead reads them in religious terms. By contrast, his observations about the harsh weather conditions in the Sonora desert, as anecdotal as they might be, deserve closer attention, particularly because they confirm the stability of the climate in this region until today: "What you build in the morning will be destroyed in the evening once the rain has come. For that reason this time from St. John's until October is called the time of the rainy weather [monsoon]. However, this year it was not very favorable, and we are afraid of a great inflation because that [wet] season has not yet arrived. The seeded fields are already parched" (ibid.).

23. In his lengthy report from 1737 he was going to repeat some of those accounts, see below.

Futhark 6 (2011)

Classen, The Scientific and Religious Exploration, 49-

67

ISSN 1886-9300 
Overall, however, we have to consider the enormous work load and stress from which Segesser suffered, being in charge of all kinds of administrative duties: "I have the impression that one could find only few post office buildings in Europe that could be compared to my house in terms of messengers and businesses. I could say that I live in the Eagle or Horse Tavern, except that here everything is eaten up without pay. Especially in this rebellious time in which it is necessary to secure our houses with soldiers" (Sept. 9, 1752).

At the end of his correspondence, Segesser was increasingly concerned with the constant attacks by the Apaches and Series, with maintaining the farm life of his mission, with the news from his family and the military and political events in Europe, and with the many administrative duties that were shouldered upon him, making it impossible for him to pursue his personal intellectual interests much further.

Nevertheless, following the pattern by other Jesuits, and setting up a model for future generations (Pfefferkorn, Och, Baegert, etc.), at one point Segesser also took the time to compose a highly detailed account about the world of the Pimería Alta, a kind of report about his anthropological, sociological, and biological field work. He wrote his treatise in 1737, completing it on July 31 , addressing it both to his brother Franz Ulrich Josef and his uncle, Jost Ranutius, the latter of which had urged him for this kind of information. The Relation was first published by a later descendent, Dr. Philipp A. von Segesser in 1886, who enjoyed a great reputation as historian and philosopher back in Lucerne. ${ }^{24}$ In 1945 Theodore E. Treutlein translated the text into English, based on camera negatives of the original, ${ }^{25}$ but he changed the format

24. "Der Bericht des P. Philipp Segesser aus der Gesellschaft Jesu über seine Mission in Sonora, 1731-1761," Katholische Schweizer-Blätter für Wissenschaft, Kunst und Leben N.F. 2 (1886): 356-75, 401-34, 465-99. The editor took considerable liberty to transcribe the text into nineteenth-century German, though he still stayed close to the original. For the accomplishments of Dr. Philipp Anton von Segesser, see Heidi Nossard-Borner, "Segesser, Philipp Anton von," Historisches Lexikon der Schweiz, online at: http://www.hls.-dhs.dss.ch/textesc/d/D4203.php (forthcoming). See also Victor Conzemius, Philipp A. von Segesser (1817-88): Demokrat zwischen den Fronten (Zürich: Benziger, 1977).

67 
to some extent, moving part of the factual information into an appendix, whereas the original had it placed right in the middle of the text.

Fully cognizant of the abundance of previous reports about the common experiences by Jesuit missionaries traveling to the New World, Segesser limits himself to the fairly sober, almost scientific, description of the Pimería Alta, focusing on the geophysical dimensions and properties, the fauna and flora, climate and people. His interest is aimed at the appearance of the Pima Indians (today Tohono O'odham), their skin color, their great pride in their waist-long hair, and bodily ornaments (143). The author expresses great amazement at their unsurpassed skill in making music without any ability to read: "That which the Pima sees or hears a single time he can reproduce very shortly better than his master. Though none can read except the choirmaster, yet they can sing the Holy Mass in unison from beginning to end" (145). For Segesser, the practice of applying tattoos on the children's bodies proves to be most intriguing, judging from the great details about this practice (145). The anthropologist in him makes him discuss all the relevant rituals associated with marriage (145), but then he quickly turns also to their willingness to confess in Church and to submit to the Christian rites (146). This also involves his study of what they believe and in how far they might be willing to accept the Jesuit's preaching about the omnipotent God and the afterlife (146).

Segesser offers many different, almost contradictory perspectives, handing out criticism of the laziness among the Pimas and praise for their amazing craftsmanship: "there are those among the Pimas who are very skillful and who fabricate things of fibers, straw, cotton, and other material in a way that moves Europeans to wonderment" (147). Or: "they make cotton tablecloths and other things which are only a little inferior to those made in my fatherland" (ibid.). The way how adobe houses are built receives considerable attention (147-

25. Theodore E. Treutlein, "The Relation of Philipp Segesser," Mid-America: An Historical Review NS. 16 [27), 3 (1945): 139-260. It is not clear to me whether the copy from which the negatives were made was the original one, housed in Bonn Jesuit College Library, because the Lucerne State Archive also holds a manuscript copy, and I could not tell from the handwriting whether the latter was the one written by Philipp Segesser himself, or a copy by one of his Swiss relatives.

67 
49), though Segesser does not refrain from ridiculing the Indians again for their lack of expertise as stone masons (148).

It would not be reasonable to list all the aspects mentioned by the author because he tries, indeed, to cover almost everything of relevance or that might strike his readers as unusual and interesting both in anthropological and biological terms. His interest turns to wine-making, edible fruit, raising crops, smoking tobacco, then again to the allegedly low morality among the Pimas who, as he says, never hesitate to steal whenever an opportunity arises (151). The military conflicts among the various Indian tribes also gain his attention (153-154), as do the acclaimed sorcerers, one of whom, as Segesser sees it, actually tried to poison him. The nocturnal festivities, which were probably nothing but native religious ceremonies with dancing and singing, considerably bothered him, though no one had enough power or willingness to suppress them (157).

As we learn from his letters, the missionary observed these religious practices with discomfort and considerable unease, but he was helpless and could do nothing but to tolerate them. But his lack of understanding also extended to specific rituals concerning dying people as he observed them among the Pimas. Segesser bitterly comments that they did not care for the sick and simply abandoned them, as he perceived it, in their last hours. In fact, the death of a person meant normally that they burned the house and could even abandon the entire settlement (158). At the same time, as we are informed, "The Pimas, even converts, place food on the graves of their dead in the belief that the deceased will eat in the other world" (158). Most interestingly, the horse which had carried the dead person to the grave, was set free, although the missionary had desired to acquire it for himself: "rather they wished to set it free" (159).

The further details do not concern us here, nor how we have to evaluate the missionary's obvious inability to comprehend the foreign culture. There is no doubt that despite all his linguistic efforts and concern with the native people Segesser ultimately failed in understanding the other cultures and religions. In fact, he did not even grasp that he was confronted with a foreign religion per se. Nevertheless, as a reporter he provides most valuable anthropological insights and

67 
specific information that reflect his sharp eye and curiosity as a scientist, if we may call him that in this specific context.

But we also need to distinguish between the first and the second part of his report because he demonstrates much more the interest of a biographer and a historian at first, whereas later he provides extensive information about the fauna and flora of the Sonoran desert. Beginning with a discussion of the vegetation and garden crops (179), Segesser made an extensive effort to be as encyclopedic as possible in the limited time available to him. In this section he turns his attention to the weather conditions (182-183), the available mineral resources, discussing the metals and opportunities of mining (183-184), the chances to maintain livestock (184-186), and the wild animals (186, 257-60). The author demonstrates a remarkable diligence and a meticulous effort to record all aspects as completely as possible, providing also numerous comparisons with reptiles or insects in Europe, such as: "The scorpion found here is of a different variety from the bottled scorpions sold by Italians in Germany. It is called alagran [sic] and is very numerous" (257). The same applies to the variety of spiders, the chameleon, grasshoppers, wasps, etc.

Segesser also revealed great interest in birds, describing the various kinds that he witnessed, commenting on their colors and sizes. His curiosity went so far that he even announced his plan to send to his relatives in Switzerland a killed and stuffed bird that amazed him more than any others, probably meaning the humming bird: "It is called curparosa and like the bee takes its nourishment from the flowers, always on the wing" (258). But then the critical observer/scientist in him is suddenly complemented by the deeply religious person that he was: "In this bird one can recognize the wonderful omnipotence of God" (ibid.) - a quite common phenomenon among the Jesuit missionaries. Segesser also addressed the availability of fish, but lamented of their scarcity, which made it almost impossible for him to meet the requirements for a good Catholic to fast by way of refraining from meat except for fish (259).

Finally, Segesser also addressed astronomical phenomena, such as the eclipse of the moon, though his efforts to explain it and the

67 
change of colors of the moon stay mostly on a dilettante level. ${ }^{26}$ Regarding a comet, he ventured into some religious interpretations, and we can be certain that neither mathematics, to which he refers repeatedly in this context, nor astronomy were among his major intellectual skills. On the other hand, as his final statement reveals, Segesser was very clear about the high level of scientific expertise available among the Jesuits, especially back home at the university of Ingolstadt, to whom he refers with considerable respect: "I do not know whether or not these things were better observed in Europe. If they were, one of our mathematicians in Ingolstadt may give more information about them. These signs were forebodings of evil times which I soon had to experience. Comets seldom bring good things with them" (260).

To conclude, Segesser proves to be a fascinating observer and writer, whose correspondence and critical report about the new world where he lived for the rest of his life until 1762 contained numerous significant information both about the concrete aspects concerning the fauna and flora and the various cultural phenomena as expressed by the native population. Segesser was not a scientist in the narrow sense of the word, but as a missionary who lived all by himself among the American Indians he could not help but to reflect in a critical fashion upon the many natural aspects characterizing his environment. Of course, Segesser operated in many respects just as the conditions in his mission demanded from him, but both the letters and his treatise indicate the high level of perceptivity and curiosity. On this basis he was in fact able to relay to his audience a wealth of new information concerning the climate, geography, biology, and geology of the Sonoran desert and its peoples.

We might even want to go so far as to argue that missionaries hardly could avoid making scientific observations considering their isolation and lack of distractions, but it certainly required the kind of educational background provided by a Jesuit school system to be able to take the additional step from being nothing but an ordinary missionary to being a sharp observer and scientist in one's own rights. Segesser does not seem to have achieved quite the same level of sophistication as

26. This is also Treutlein's opinion, note on p. 259.

67 
Kino, for instance, but he was certainly highly attuned to the expectations by his readers back home who wanted to learn from him as much about the New World as possible. 